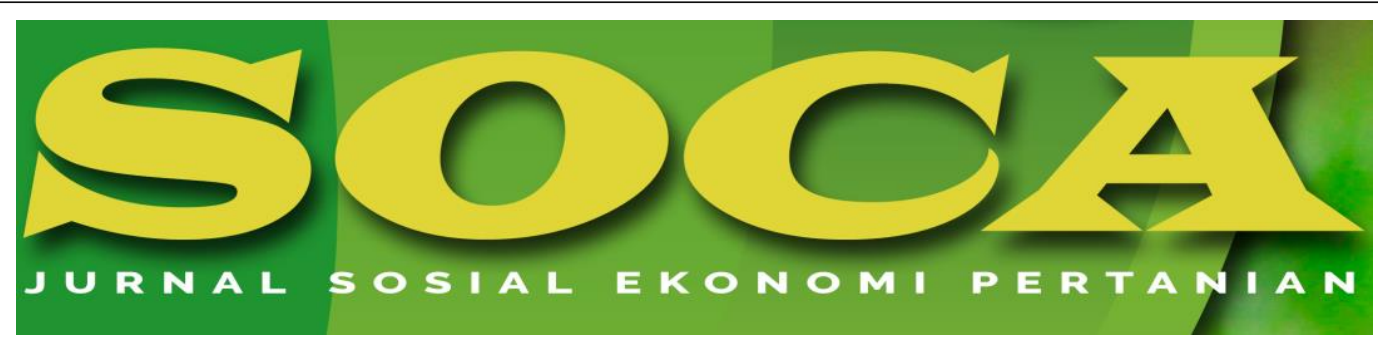

https://ojs.unud.ac.id/index.php/soca

\title{
The Productivity and Income of Corn Farming Business through the Application of Biological Fertilizers
}

\author{
Joni Karman, Suparwoto and Yanter Hutapea \\ Assessment Institute for Agricultural Technology South Sumatra \\ E-mail: jkarman3@gmail.com, suparwoto11@gmail.com and hutapeayanter@yahoo.co.id \\ Mobile: 081363931986, 0821175323647 and 081367600468
}

Submitted: March 19th, 2020; Revised: April 16th 2020; Accepted: May 20th 2020

\begin{tabular}{l}
\hline Keywords: \\
Biological \\
fertilizers; \\
Agrimeth; corn; \\
production; \\
income \\
\hline
\end{tabular}

Keywords:

Biological

fertilizers;

production;

income

\begin{abstract}
The use of microbes' research as biological fertilizers in order to increase corn production had been performed, but the analysis of farming business related to this matter has not been conducted. This research aimed to determine the effect of one of the biological fertilizers, which was Agrimeth, on the seeds of various composite corns to the growth factors, the productivity of corn farming in dry land, and the amount of income that was obtained. This research was conducted in Betung Village, Betung Sub-District, Banyuasin Regency, South Sumatra. The corn varieties used were Bima 10, Bima 19, and Sukmaraga. The results showed that the seed treatment of corn seeds with Agrimeth showed an improvement trend of plant height, number of leaves, cob length and diameter, weight of 100 dry shelled grains, dry shelled production, and $\mathrm{R} / \mathrm{C}$ in each variety. The application of Agrimeth biological fertilizers increased corn farming in dry land with R / C 2.79; 2.65; and 1.82 for each Bima 10, Sukmaraga and Bima 19 varieties.
\end{abstract}

How to Cite (APA $6^{\text {th }}$ Style):

Karman, J., Suparwoto, \& Hutapea, Y. (2020). The Productivity and Income of Corn Farming Business through the Application of Biological Fertilizers. SOCA: Jurnal Sosial Ekonomi Pertanian, 14(3), 433-443. https://doi.org/https://doi.org/ 10.24843/SOCA.2020.v14.i03.p05 


\section{INTRODUCTION}

Corn is an important commodity in the Indonesian food system that acted as the main food for some population in various regions. Also, being the main food for the poultry industry, and basic ingredient for processed food industry (Suryana and Agustian, 2014). With such a large role in the food system in Indonesia, so the efforts to increase corn production and productivity must continue to be developed. The central government had an important role in production policies related to the policy of fertilizer subsidies, land development and irrigation, and technological innovation (Dermoredjo, 2014).

The corn productivity depended on nutrition needs and management, especially nitrogen, phosphorus, and potassium. The high cost of inorganic fertilizers including the inability to condition the soil and its influence on the environment has directed concern to other soil fertilization sources to increase corn production (Kumar et al., 2019). The use of organic fertilizer (compost) was one of the efforts that made to increase plant nutrient absorbency, so that the use of inorganic fertilizers can be done more efficiently. Wilujeng and Handayanto (2019) reported an increase in corn production with compost application of 20 tons per hectare. The use of compost was often constrained by a lot of needs so that it increased production costs significantly.

The biological source research that can improve the efficiency of the use of inorganic fertilizers and production costs was needed. Microorganisms were involved in various processes that affected the transformation of soil phosphorus and atmospheric nitrogen into forms that can be used for plant growth. There was some evidence that growth and increase in crop yields can be stimulated by plant growthbooster bacteria because of its ability to fix nitrogen, phosphate solubility, and production of plant growth hormones (Zaeim, et al., 2017). The researches with microbial inoculants and nutrients have showed that some inoculants can increase plant nutrient absorbency and thus increased the efficiency of using chemical fertilizers and manure (Adesemoye and Kloepper, 2009). So, fertilizer efficiency by utilizing microorganisms was one of the methods that can be taken to achieve this. One of the biological fertilizer products of the Ministry of Agriculture's Research and Development Institution was Agrimeth, which consisted of several bacteria, which were Azotobacter vinelandi (moored non-symbiotic N2 and soil solvent P), Azospirillum sp. (moored non-symbiotic N2 and phytophormone producer), Bacillus cereus (soil solvent $\mathrm{P}$, anti-pathogenic compounds producer), Bradyrhizobium sp. (moored symbiotic N2), and Methylobacterium sp. which also produced phytophormone (Afandi, 2013).

Although several researches on microbes' application as biological fertilizers to increase corn production had been performed, but analysis of farming business related to that matter has not been performed. This research aimed to determine the effect of one of the biological fertilizers, which was Agrimeth, on the seeds of various composite corns to the growth factors, the productivity of corn farming business in dry land, and the amount of income obtained. 


\section{RESEARCH METHODS}

This research was conducted in Betung Village, Betung Sub-District, Banyuasin Regency South Sumatra. The corn varieties used were Bima 10, Bima 19, and Sukmaraga. Before planting, corn was coated with biological fertilizer containing a microbial consortium of Azotobacter vinelandii, Azospirillum sp., Bacillus cereus, Bradyrhizobium sp., and Methylobacterium sp. (in the Agrimeth brand packaging, produced by the Indonesian Study Center of Agricultural Land Resources, Ministry of Agriculture). The treatments applied were seed treatment with Agrimeth and without seed treatment.

The research was performed on dry land owned by farmers. The area of each plot per treatment was $20 \mathrm{~m} \times 20 \mathrm{~m}$. Each treatment was repeated 4 times. Seeds were planted by making a hole with sharp stick where one hole was one seed, with a spacing of $70 \mathrm{~cm} \times 20 \mathrm{~cm}$. Fertilization of corn plants with a dose of $350 \mathrm{~kg} / \mathrm{ha}$ Urea, $200 \mathrm{~kg} / \mathrm{ha}$ SP-36 and $100 \mathrm{~kg} / \mathrm{ha} \mathrm{KCl}$. Fertilization was done twice, which were at the age of 1 week after planting (MST) with a dose of $150 \mathrm{~kg}$ urea, $200 \mathrm{~kg}$ SP36 and $100 \mathrm{~kg} \mathrm{KCl} /$ ha and at the age of 4 weeks after planting (MST) with a dose of $200 \mathrm{~kg}$ urea / ha, given by lining between corns plants. Agrimeth was given at a dose of 400 grams for $25 \mathrm{~kg}$ of seeds. Variables that observed were plant height, number of leaves, cob length and diameter, weight of 5 wet cobs, weight of 100 dry shelled grains, and dry shelled production, analyzed by t-test.

Analysis of corn farming business was done by calculating the value of revenue-cost ratio $(\mathrm{R} / \mathrm{C})$, breakeven point price and breakeven point production (Hendayana, 2016 and Suratiyah, 2009). Analysis of breakeven point price and breakeven point production was used to determine the price limit of each product sale price and the amount of product that must be produced so that the farming business did not loss. The farming expectation was that the actual production result was higher than the breakeven point production and the breakeven point price must be lower than the actual selling price.

$$
\mathrm{R} / \mathrm{C}=\frac{T R}{T C}
$$

Where;

$$
\begin{array}{ll}
\mathrm{R} & =\text { Income } \\
\mathrm{C} & =\text { Cost } \\
\mathrm{TR} & =\text { Total income } \\
\mathrm{TC} & =\text { Total cost } \\
\mathrm{If} \mathrm{R} / \mathrm{C}>1, \text { farming business economically profitable } \\
\mathrm{R} / \mathrm{C} \quad=1, \text { farming business economically in breakeven point } \\
\mathrm{R} / \mathrm{C} \quad<1, \text { farming business economically experience loss }
\end{array}
$$

$$
\mathrm{TIH}=\frac{T C}{Y}
$$

Where;

$$
\begin{array}{ll}
\mathrm{TIH} & =\text { Breakeven point price } \\
\mathrm{Y} & =\text { Production }
\end{array}
$$




$$
\mathrm{TIP}=\frac{T C}{P}
$$

Where;

$$
\begin{array}{ll}
\mathrm{TIP} & =\text { Breakeven point production } \\
\mathrm{P} & =\text { Price }
\end{array}
$$

\section{RESULTS AND DISCUSSION}

\section{The Plant Height and Number of Leaves}

The research result showed that corn seeds treatment with Agrimeth can improve the height of the plant. There was a significance different on the plant height of Bima 10 and Bima 19 varieties, between seeds that got seed treatment with Agrimeth and seed that planted without seed treatment. Meanwhile in Sukmaraga variety, seeds that got seed treatment, were higher in growth than seeds without seed treatment, but the difference was not significance. (Table 1)

Table 1. Plant height and number of leaves of some composite corn varieties with and without Agrimeth biological fertilizers application

\begin{tabular}{lcccc}
\hline \multirow{2}{*}{ Variety } & \multicolumn{2}{c}{ Plant Height } & \multicolumn{2}{c}{ Number of Leaves } \\
\cline { 2 - 5 } & A & B & A & B \\
\hline Bima 10 & $182,47 \mathrm{a}$ & $205,83 \mathrm{~b}$ & $9,13 \mathrm{a}$ & $10,67 \mathrm{~b}$ \\
Bima 19 & $185,93 \mathrm{a}$ & $206,33 \mathrm{~b}$ & $9,47 \mathrm{a}$ & $9,33 \mathrm{~b}$ \\
Sukmaraga & $187,40 \mathrm{a}$ & $195,00 \mathrm{a}$ & $9,03 \mathrm{a}$ & $9,33 \mathrm{a}$ \\
\hline
\end{tabular}

Information

A = without Agrimeth, B = with Agrimeth

Source: Processed from primary data (2019)

One of the microbes contained in Agrimeth was Methylobacterium spp., which was capable of producing quite high gibberelline phytohormone. Gibberellins were promoters of seed germination and can activate hydrolysis enzymes (a-amylase) found in endosperm (Danial et al. 2014). Gibberellins were compounds consisted of a gibbane skeleton which had biological activities that affected physiological characters such as elongation, division, cell enlargement, and stimulation of flowering. Darusandi (2012). The allocation of gibberellins can increase cambium activity and xylem development so that growth activity goes smoothly and quickly. Irvan and Adriana (2017) reported that gibberellins significantly affected the height of fragrant pandan rice plants.

The other microbes contained in Agrimeth were assumed also have a role in plant height growth. Ambarsari et al. (2016) reported that Azotobacter sp. inoculation had a significant effect on the growth of Shorgum bicolor. Sadrood et al (2013) also reported that the application of biological fertilizers that contain Azotobacter and Azospirillum increased plant growth and yield, and reduced the use of chemical fertilizer doses.

Agrimeth application showed different effects on the number of leaves in various varieties of corn. In the Bima 10 variety, plants that were applied with seed treatment with Agrimeth had significantly different leaves than plants that were not applied with seed treatment with Agrimeth. Whereas in Bima 19 and Sukmaraga varieties; there was no significant difference in the number of leaves between the 
plants that were applied to Agrimeth seed treatments and those that were not applied. Astuti and Purba (2017) reported that Agrimeth $200 \mathrm{~g} \mathrm{ha}^{-1}+$ Gliocompost biological fertilizer $20 \mathrm{~kg} \mathrm{ha}^{-1}+$ recommended fertilizer hasd a significant effect on plant growth, which were plant height, number of leaves, number of nodules, number of flowers, number of filled pods and soybean yield. The better growth of nodules, which caused the ability of the roots to absorb water and bind the nutrients $\mathrm{N}, \mathrm{P}$, and $\mathrm{K}$ through increasing soils colloidal to support the plant growth and development.

An increase in plant height and number of leaves were identical to an increase in dry weight of crop waste. An increase in plant height and number of leaves indicated an increase in plant nutrient absorbency. Plants that can absorb nutrients better will be able to produce higher production. The data in Table 1 and Table 3 showed that there was a similar pattern between the tendency to increase plant height, number of leaves, and dry shelled production due to seed treatment with Agrimeth. Kasno and Rostaman (2013) reported an increase in dry weight of crop waste and dry shelled weight in corn plants which were given various fertilization treatments compared to controls.

\section{Cob length and diameter, weight of 100 dry shelled seeds, and production}

The seed treatment with Agrimeth did not show any significant difference in the length of the cobs in the Bima 10, Bima 19, or Sukmaraga varieties, although they generally showed a longer trend. While in measuring the diameter of the cob, the treatment with Agrimeth showed significant differences in the Sukmaraga variety (Table 2).

Table 2. Cob length and diameter of some composite corn varieties with and without Agrimeth biological fertilizer application

\begin{tabular}{lcccc}
\hline \multirow{2}{*}{ Variety } & \multicolumn{2}{c}{ Cob length } & \multicolumn{2}{c}{ Cob diameter } \\
\cline { 2 - 5 } & A & B & A & B \\
\hline Bima 10 & $18,00 \mathrm{a}$ & $19,03 \mathrm{a}$ & $45,53 \mathrm{a}$ & $42,67 \mathrm{a}$ \\
Bima 19 & $16,79 \mathrm{a}$ & $15,93 \mathrm{a}$ & $42,73 \mathrm{a}$ & $43,33 \mathrm{a}$ \\
Sukmaraga & $16,79 \mathrm{a}$ & $18,50 \mathrm{a}$ & $45,00 \mathrm{a}$ & $47,67 \mathrm{~b}$ \\
\hline
\end{tabular}

Information

A = without Agrimeth, B = with Agrimeth

Source: Processed from primary data (2019)

The weight of the cob was related to the length and diameter of the cob. An increasing in the length and diameter of the cob tended to increase the weight of the sweet corn cobs (Meity et al., 2012). Nugroho et al. (1999) stated that the increase in the weight of cob on sweet corn plants was in line with the increased efficiency of the photosynthetic process and the rate of photosynthate translocation to the cob. The results showed that seed treatment with Agrimeth in general had no significant effect on increasing the length and diameter of corn cobs. Except for the Sukmaraga variety, where seed treatment with Agrimeth significantly affected the increase in cob diameter.

The seed treatment application generally showed a trend of increasing seed weight, although not significantly. A significant difference in the weight of 100 dried 
shelled seeds was shown in Bima 19 variety which coated with Agrimeth. The Sukmaraga variety showed a trend of increasing the weight of 100 dry shelled seeds, but the difference was not significant. Whereas in the Bima 10 variety, there were no differences in the weight of 100 dry shelled seeds between treatments.

Table 3. Weight of 100 dry shelled seeds and dry shelled production of some composite corn varieties with and without Agrimeth biological fertilizer application

\begin{tabular}{lcccc}
\hline \multirow{2}{*}{ Variety } & \multicolumn{2}{c}{ weight of 100 dry shelled } & \multicolumn{2}{c}{$\begin{array}{c}\text { dry shelled production } \\
\text { (ton/ha) }\end{array}$} \\
\cline { 2 - 6 } & seeds & B & A & B \\
\hline Bima 10 & $32,00 \mathrm{a}$ & $32,00 \mathrm{a}$ & $7,81 \mathrm{a}$ & $8,78 \mathrm{a}$ \\
Bima 19 & $27,00 \mathrm{a}$ & $31,00 \mathrm{~b}$ & $4,88 \mathrm{a}$ & $5,40 \mathrm{~b}$ \\
Sukmaraga & $33,67 \mathrm{a}$ & $35,00 \mathrm{a}$ & $7,49 \mathrm{a}$ & $8,33 \mathrm{a}$ \\
\hline
\end{tabular}

Information

A = without Agrimeth, B = with Agrimeth

Source: Processed from primary data (2019)

Besides being influenced by genotype and environmental factors, seed treatment with Agrimeth might also increase the ability of corn to optimize the photosynthetic process and the rate of photosynthate translocation. Increased seed weight was assumed to be related to the amount of photosynthate that was partitioned into the cob. The greater the photosynthate allocated to the cob, the greater the accumulation of food reserves that were transplanted to the seeds, thereby increasing the weight of the seeds (Yaumalika et al., 2017). Wahyudin et al. (2016) stated that the ability of corn to utilize growth factors that used for photosynthesis and the rate of photosynthate translocation that used to form and enlarge seeds resulting high dry weight of 100 seeds.

\section{Farming Business Analysis}

In general, the application of seeds with Agrimeth affected yields. Corn that was given Agrimeth application produced more crops than corn that was not given Agrimeth application. In addition, the yield was also influenced by the variety of corn that planted. The highest production was produced by the Bima 10 variety, then the Sukmaraga variety, and the lowest was the Bima 19 variety. With almost the same labor costs, with a little additional cost for purchasing and treating Agrimeth, the Agrimeth application turned out to be greater yields and incomes. This can be proven by the analysis of corn farming with Agrimeth application had a higher R / C value compared to corn farming without Agrimeth application.

Table 4. Farming business production facilities cost of some composite corn varieties with and without Agrimeth biological fertilizer application

\begin{tabular}{lrrrrrrr}
\hline \multirow{2}{*}{ Description } & \multirow{2}{*}{ Volume } & \multicolumn{2}{c}{ Bima 10 } & \multicolumn{2}{c}{ Bima 19 } & \multicolumn{2}{c}{ Sukmaraga } \\
\cline { 3 - 8 } & & \multicolumn{1}{c}{$\mathbf{A}$} & \multicolumn{1}{c}{ B } & \multicolumn{1}{c}{ A } & \multicolumn{1}{c}{ B } & \multicolumn{1}{c}{ A } & \multicolumn{1}{c}{ B } \\
\hline Seeds & $15,75 \mathrm{~kg}$ & 1.102 .500 & 1.102 .500 & 1.102 .500 & 1.102 .500 & 1.102 .500 & 1.102 .500 \\
Urea & $395 \mathrm{~kg}$ & 2.283 .750 & 2.283 .750 & 2.283 .750 & 2.283 .750 & 2.283 .750 & 2.283 .750 \\
SP-36 & $225 \mathrm{~kg}$ & 1.530 .000 & 1.530 .000 & 1.530 .000 & 1.530 .000 & 1.530 .000 & 1.530 .000 \\
KCl & $115 \mathrm{~kg}$ & 765.000 & 765.000 & 765.000 & 765.000 & 765.000 & 765.000 \\
Pesticide & $1 \mathrm{Pkg}$. & 855.000 & 855.000 & 855.000 & 855.000 & 855.000 & 855.000 \\
\hline
\end{tabular}




\begin{tabular}{|c|c|c|c|c|c|c|c|}
\hline Sack & 360 Sht & 720.000 & 720.000 & 720.000 & 720.000 & 720.000 & 720.000 \\
\hline Agrimeth & $2 \mathrm{sch}$ & - & 225.000 & - & 225.000 & - & 225.000 \\
\hline & & 7.256 .250 & 7.481 .250 & 7.256 .250 & 7.481 .250 & 7.256 .250 & 7.481 .250 \\
\hline
\end{tabular}

Information

A = without Agrimeth, B = with Agrimeth

Source: Processed from primary data (2019)

The amount of costs for Bima 10 production facilities without and with Agrimeth application were 44.32\% and 44.15\%, Bima 19 without and with Agrimeth application were $47.01 \%$ and $47.85 \%$, while Sukmaraga without and with the Agrimeth application were $44.32 \%$ and $44.15 \%$ of the total production costs. The most needed production facility costs were fertilizer purchasing, which was around $67.83 \%$ of the production facility costs or around $31.16 \%$ of the total production costs. Costs required to buy corn seeds were small, which was around $16.33 \%$ of the cost of production facilities. While the costs required to purchase Agrimeth biological fertilizers were very small which only $3.33 \%$ of production facilities costs.

Table 5. Farming business labor costs of some composite corn varieties with and without Agrimeth biological fertilizer application

\begin{tabular}{lrrrrrr}
\hline \multirow{2}{*}{ Description } & \multicolumn{2}{c}{ Bima 10 } & \multicolumn{2}{c}{ Bima 19 } & \multicolumn{2}{c}{ Sukmaraga } \\
\cline { 2 - 7 } & \multicolumn{1}{c}{ A } & \multicolumn{1}{c}{ B } & \multicolumn{1}{c}{ A } & \multicolumn{1}{c}{ B } & \multicolumn{1}{c}{ A } & \multicolumn{1}{c}{ B } \\
\hline Land & 1.687 .500 & 1.687 .500 & 1.687 .500 & 1.687 .500 & 1.687 .500 & 1.687 .500 \\
Cultivation & 1.350 .000 & 1.350 .000 & 1.350 .000 & 1.350 .000 & 1.350 .000 & 1.350 .000 \\
Planting & 337.500 & 337.500 & 337.500 & 337.500 & 337.500 & 337.500 \\
Weeding & 1.181 .250 & 1.181 .250 & 1.181 .250 & 1.181 .250 & 1.181 .250 & 1.181 .250 \\
Embellishment & 450.000 & 450.000 & 450.000 & 450.000 & 450.000 & 450.000 \\
Fertilization & 675.000 & 675.000 & 675.000 & 675.000 & 675.000 & 675.000 \\
Spraying & 562.500 & 562.500 & 450.000 & 450.000 & 562.500 & 562.500 \\
Harvesting & 1.181 .250 & 1.181 .250 & 742.500 & 742.500 & 1.181 .250 & 1.181 .250 \\
Shelling & 787.500 & 787.500 & 495.000 & 495.000 & 787.500 & 787.500 \\
Drying & & & & & & \\
\hline \multicolumn{1}{c}{ Total } & 8.212 .500 & 8.212 .500 & 7.368 .750 & 7.368 .750 & 8.212 .500 & 8.212 .500 \\
\hline
\end{tabular}

Information

A = without Agrimeth, B = with Agrimeth

Source: Processed from primary data (2019)

Fertilizer was one of the major expenses in corn cultivation. Dermoredjo (2014) stated that the sequence of the main policy alternatives for corn commodities, both in Java and outside Java was the same, which were the provision of fertilizer subsidies, the provision of production facilities, technological innovation, and intensification of farming business, and land development and irrigation. Suryana and Agustian (2014) stated that productivity improvement was performed through the dissemination of inbred and hybrid superior seeds and the application of location-specific corn cultivation techniques. Meanwhile, the output price policy in the form of a base price had not been implemented since 1990.

The labor costs in this corn farming business were greater than the costs of production facilities. The labor needs included in land management, planting, weeding, embellishment, fertilizing, spraying, harvesting, shelling and drying. The biggest labor cost was on land management, which was around $20.68 \%$ of the cost 
of labor. The need for planting costs was close to the cost of land cultivation, which was about $16.55 \%$ of the labor cost requirements. The amount of costs for Bima 10 labors without and with the Agrimeth application were 55.68\% and 54.85\%, Bima 19 without and with the Agrimeth application were $52.99 \%$ and $52.15 \%$, while Sukmaraga without and with the Agrimeth application were $55.68 \%$ and $54.85 \%$ of the total production costs. Then the total production costs incurred for corn farming in this research were for Bima 10 without and with the application of Agrimeth was Rp. 15,468,750, - and Rp. 15,693,750, -, for Bima 19 without and with the Agrimeth application was Rp. 14,625,000 and Rp. 14,850,000. While the total production cost for Sukmaraga without and with the Agrimeth application was the same with Bima 10 .

Table 6. Farming Business Analysis of some composite corn varieties with and without Agrimeth biological fertilizer application

\begin{tabular}{lrrrrrr}
\hline \multirow{2}{*}{ Description } & \multicolumn{2}{c}{ Bima 10 } & \multicolumn{2}{c}{ Bima 19 } & \multicolumn{2}{c}{ Sukmaraga } \\
\cline { 2 - 8 } & \multicolumn{1}{c}{ A } & \multicolumn{1}{c}{ B } & \multicolumn{1}{c}{ A } & \multicolumn{1}{c}{ B } & \multicolumn{1}{c}{ A } & \multicolumn{1}{c}{ B } \\
\hline Dry shelled & 7.808 & 8.775 & 4.883 & 5.400 & 7.493 & 8.325 \\
(kg/ha) & & 43.875 .000 & 24.415 .000 & 27.000 .000 & 37.465 .000 & 41.625 .000 \\
Income (Rp/ha) & 39.040 .500 & & & & & \\
Production cost & 15.468 .750 & 15.693 .750 & 14.625 .000 & 14.850 .000 & 15.468 .750 & 15.693 .750 \\
(Rp/ha) & & & & & & \\
Profit (Rp/ha) & 23.571 .750 & 28.181 .250 & 9.790 .000 & 12.150 .000 & 21.996 .250 & 25.931 .250 \\
TIH (Rp/kg) & 1.981 & 1.788 & 2,995 & 2.750 & 2.064 & 1.885 \\
TIP (kg/ha) & 3.094 & 3.139 & 2.925 & 2.970 & 3.094 & 3.139 \\
R/C & 2,52 & 2,79 & 1,67 & 1,82 & 2,42 & 2,65 \\
\hline
\end{tabular}

Information

A $=$ with Agrimeth, $B=$ without Agrimeth

Source: Processed from primary data (2019)

Table 6 showed the analysis of corn farming business conducted in this research profitable to all the varieties tested. This was indicated by the $\mathrm{R} / \mathrm{C}$ value greater than 1 in all varieties. The highest R / C was found in the Bima 10 variety (2.52 and 2.79), then Sukmaraga variety (2.42 and 2.65), and the lowest R / C was in the Bima 19 variety (1.67 and 1.82). This showed that, using Agrimeth with relatively small input values can increase the $\mathrm{R} / \mathrm{C}$ value of corn farming.

From farming business, it was expected that the actual production obtained was higher than the TIP and the selling price of the product was higher than the TIH. The difference between the actual product and the breakeven point of production (TIP) determined the amount of the income value. The higher the actual product' gap with the TIP, so that the higher the income. From the business analysis conducted, the highest gap between the actual product and the TIP was the Bima 10 which was given Agrimeth, with a product gap of $5,636 \mathrm{~kg} / \mathrm{ha}$, proven by the highest value of income, which was $28,181,250 \mathrm{Rp} /$ ha. The lowest gap between the actual product and the TIP was Bima 19 without Agrimeth, giving a product gap of only 1,958 kg/ha,

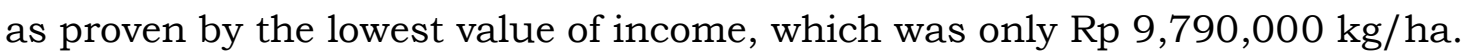

The selling price of dry shelled corn was Rp 5,000/kg. The greater the gap between the breakeven point of price (TIH) and the actual selling price of the product, so that the greater the income. The selling price gap with the highest break-even 
point of Rp 3,212/kg was shown by Bima 10 with Agrimeth, while the lowest Rp $2,005 / \mathrm{kg}$ was shown by Bima 19 without Agrimeth.

Table 6 showed that the application of Agrimeth in corn cultivation can increase productivity, increase farmers' income, which was also accompanied by an increase in $\mathrm{R} / \mathrm{C}$. Through intensification, efforts were made primarily by increasing population per unit area of planting, or optimize fertilization so it can increase productivity. The challenge in intensification was in the form of technological innovation, especially on marginal lands, where nutrients were poor, or nutrients were bound, so that nutrient absorbency by plants was not optimal. The use of compost to improve land conditions and roots was one method that can be used to increase production. Widodo and Kusuma (2018) reported that composting caused changed in soil physical character (aggregate stability, content weight, and soil pores) that affected the growth of corn. The result of correlation from soil physical character (aggregate stability, content weight, and soil pores) to the growth of plants showed a positive correlation.

The use of compost was often constrained by many needs, thus increasing input significantly. Wilujeng and Handayanto (2019) reported an increase in corn production with an application of 20 tons per hectare of compost. Agrimeth application (biological fertilizer) can be used to complement the innovations needed in the intensification of corn farming business by considering the benefits that received by farmers.

\section{CONCLUSION}

The application of Agrimeth biological fertilizers to corn plants showed an improved trend in plant height, number of leaves, cob length and diameter, and production in composite corn varieties of Bima 10, Bima 19, and Sukmaraga. The application of Agrimeth biological fertilizers increased corn farming business in dry land with R/C 2.79; 2.65; and 1.82 for each Bima 10, Sukmaraga and Bima 19 varieties.

\section{RECOMMENDATION}

To find out the efficiency of using inorganic fertilizers with the application of biological fertilizers, so that reduce the production costs of corn farming business, it was necessary to do more in-depth research by reducing the use of inorganic fertilizer doses used with the economies scale.

\section{THANK-YOU NOTE}

The author would like to thank the Head of the Agricultural Technology Study Center of South Sumatra, through the funding for this research and Mr. H. Suginen for providing the location of the activity.

\section{REFERENCES}

Adesemoye, A.O. and Kloepper, J.W. (2009). Plant-Microbes Interactions in Enhanced Fertilizer-Use Efficiency. Appl Microbiol Biotechnol. 2009 Nov; 85(1):1-12. doi: $10.1007 / \mathrm{s} 00253-009-2196-0$ 
Afandi M.K. (2013). Peningkatkan Produktivitas dengan Pupuk Hayati, Majalah Sains Indonesia, 24:67. http://www.litbang.pertanian.go.id/artikel/one/ 320/pdf/Pupuk\%20Hayati.pdf

Ambarsari, H., Udayani, J.E., Mulyono, dan Akhadi, D.H. (2016). Pengaruh Penambahan Inokulum Azotobacter sp. terhadap Pertumbuhan Tanaman Sorghum bicolor untuk Aplikasi Fitoremediasi. Jurnal Teknologi Lingkungan Vol. 17, No 1, Januari 2016, 1-6

Astuti, Y., dan Purba, R. (2017). Respon Pertumbuhan dan Hasil Kedelai terhadap Pupuk Hayati di Lahan Sawah Di Kabupaten Pandeglang, Banten. Agrovigor 10 (1): 28- 32 (2017).

Danial D., Widajati, E. dan Salma, S.(2014). Pengaruh Teknik Aplikasi Methylobacterium spp Terhadap Pertumbuhan dan Hasil Kedelai. Prosiding Seminar Hasil Penelitian Tanaman Aneka Kacang dan Umbi 2014.

Darusandi, D. (2012). Pengaruh Waktu Aplikasi dan Konsentrasi Asam Giberelat (Ga3) terhadap Pertumbuhan dan Hasil Baby Corn (Zea Mays Saccharata Sturt). [Thesis]. Fakultas Pertanian. Universitas Andalas.

Dermoredjo, S.K. (2014). Analisis Kebijakan Pengembangan Padi, Jagung, dan Kedelai di Indonesia dalam Menghadapi Perdagangan Bebas ASEAN. Analisis Kebijakan Pertanian. Volume 12 Nomor 1. Juni 2014.

Hendayana, R. 2016. Analisis Data Pengkajian. IAARD Press. 180 hal.

Irvan, A dan Adriana, A. (2017). Pengaruh Zat Pengatur Tumbuh (ZPT) Daminozid dan Giberelin Terhadap Pertumbuhan dan Pembungaan Padi Pandanwangi. Agroscience Vol. 7 No. 2 Tahun 2017.

Kasno, A. dan Rostaman, T. (2013). Serapan Hara dan Peningkatan Produktivitas Jagung dengan Aplikasi Pupuk NPK Majemuk. Penelitian Pertanian Tanaman Pangan Vol. 32 No. 3. 2013. p. 179-186.

Kumar, A.S., Wafula, W.N., and Korir, N.K. (2019). Effect of Biofertilizer on Growth and Yield Characteristics of Zea mays L. in Different Ecological Zones in Kenya. Asian Journal of Soil Science and Plant Nutrition. 4(3): 1-7, 2019; Article no. AJSSPN.48668

Meity, G.M. Polii, dan Tumbelaka, S. (2012). Hasil Tanaman Jagung Manis (Zea Mays Saccharata L.) pada Beberapa Dosis Pupuk Organik. Eugenia Volume 18 No. 1 April 2012.

Nugroho, A., Basuki, N. dan Nasution, M.A. (1999). Pengaruh Pemberian Pupuk Kandang dan Kalium Terhadap Kualitas Jagung Manis pada Lahan Kering. Habitat 10 (105). p. 33-38.

Sardrood, S.N.E., Raei, Y., Pirouz, A.B., and Shokati, B. (2013). Effect of Chemical Fertilizers and Bio-Fertilizers Application on Some Morpho-Physiological Characteristics of Forage Sorghum. International Journal of Agronomy and Plant Production. Vol., 4 (2), 223-231, 2013

Suratiyah, K. 2009. Ilmu Usahatani. Penebar Swadaya, Jakarta, 123 hal. 
Suryana, A. dan Agustian, A. (2014). Analisis Dayasaing Usahatani Jagung di Indonesia. Analisis Kebijakan Pertanian. Volume 12 Nomor 2, Desember 2014.

Wahyudin, A., Ruminta, dan Nursaripah, S.A. (2016). Pertumbuhan dan Hasil Tanaman Jagung (Zea mays L.) Toleran Herbisida Akibat Pemberian Berbagai Dosis Herbisida Kalium Glifosat. Jurnal Kultivasi Vol. 15(2) Agustus 2016

Widodo, K.H. dan Kusuma, Z. 2018. Pengaruh Kompos Terhadap Sifat Fisik Tanah dan Pertumbuhan Tanaman Jagung di Inceptisol. Jurnal Tanah dan Sumberdaya Lahan. Vol 5 No 2 : 959-967, 2018

Wilujeng, R. dan Handayanto, E. 2019. Perbaikan Produksi Tanaman Jagung pada Ultisol Menggunakan Abu Terbang Batubara dan Kompos Tandan Kosong Kelapa Sawit. Jurnal Tanah dan Sumberdaya Lahan Vol 6 No 1 : 1043-1054, 2019

Yaumalika, M., Rahayu, A., dan Adimihardja, S.A. (2017). Uji Efektivitas Beberapa Pupuk Hayati Majemuk Cair Terhadap Pertumbuhan dan Hasil Jagung Manis (Zea mays L. saccharata). Jurnal Agronida ISSN 2407-9111. Volume 3 Nomor 1, April 2017.

Zaeim, A.N., Torkaman, M., and Ghasemeeyan, H. (2017). Effects of Biofertilizer Application on Growth and Yield of corn (Zea mays L.) : A Review. International Journal of Scientific Research in Science and Technology (IJSRST). July-August2017 [(3) 6: 245-251]. 